\title{
KEBERADAAN ULA PUCUAK (Trimeresurus barati) PADA BEBERAPA DAERAH DI SUMATERA BARAT
}

\author{
Fachrul Reza*, Yosmed Hidayat \\ gm_theviper@yahoo.co.id \\ Program Studi Pendidikan Biologi STKIP PGRI Sumatera Barat
}

(Diterima September 2015, Disetujui Desember 2015)

\begin{abstract}
Sumatra is third largest island in Indonesia with tropical climate and high snakes diversity. 127 snake species had been recorded in Sumatra. Distribution and taxonomy information of snakes in Sumatra is less especially in Province West Sumatra. One of endemic snakes in Province West Sumatra is Trimeresurus barati. There was no clear information about it's existance in Province West Sumatra. The information would be needed to recognize herpetofauna existance especially Trimeresurus barati as an endemic species in Province West Sumatra in purpose to help conservation work in future. Reserach had been done from February to August 2015 with survey method, included direct collecting in several places in Province West Sumatra, collecting public information, and speciment identification in Zoological Laboratory of STKIP PGRI Sumatera Barat. Based on this research T. barati had been found in several places in Province West Sumatra such as Paninjauan 4 speciment, Balingka 3 speciment, Matur 1 speciment (Kabupaten Agam), Batipuh 2 speciment, Sabu 1 speciment, Andaleh 1 speciment, Cagar Alam Lembah Anai 5 speciment, Tambangan 4 speciment (kabupaten Tanah Datar) and Alahan Panjang 3 speciment (Kabupaten Solok). Commonly $T$. barati had been found on $600-1000 \mathrm{~m}$ asl within temperature $12^{\circ} \mathrm{C}$ $28^{\circ} \mathrm{C}$.
\end{abstract}

Keywords: Trimeresurus barati, Exsistance, endemic

\section{ABSTRAK}

Sumatera adalah pulau terbesar ketiga di Indonesia dengan iklim tropis dan keanekaragaman ular yang tinggi. 127 jenis ular telah tercatat di Sumatra. Informasi taksonomi dan distribusi ular masih sedikit terutama di provinsi Sumatera Barat. Salah satu ular endemik yang terdapat di Sumatera Barat adalah Trimeresurus barati. Tidak ada informasi yang jelas entang keberadaan ular ini. Informasi tersebut dibutuhkan untuk mengenali keberadaan herpetofauna khususnya Trimeresurus barati yang merupakan hewan endemik Sumatera Barat, dimana selanjutnya bertujuan untuk upaya konservasi. Penelitian telah dilakukan pada bulan Februari 2015 hingga Agustus 2015 dengan menggunakan metode survei, termasuk koleksi langsung pada beberapa daerah di Sumatera Barat, pengumpulan informasi dari masyarakat dan identifikasi spesimen yang telah ada di Laboratorium Zoologi STKIP PGRI Sumatera Barat. Berdasarkan penelitian ini, telah ditemukan T.barati dibeberapa tempat yaitu di daerah Paninjauan sebanyak 4 spesimen, Balingka sebanyak 3 spesimen, Matur sebanyak satu spesimen, Batipuh sebanyak 2 spesimen, Sabu sebanyak 1 spesimen, Andaleh 
sebanyak 1 spesimen, CA Lembah Anai sebanyak 5 spesimen, Tambangan sebanyak 4 spesimen dan Alahan Panjang sebanyak 3 spesimen. Umumnya T.barati ditemukan pada daerah berketinggian 600-1000mdpl dengan suhu berkisar 12C-28C

Katakunci: Endemik, Keberadaan dan Trimeresurus barati.

\section{PENDAHULUAN}

Indonesia merupakan negara kepulauan yang terdiri dari sekitar 17.000 pulau dengan ukuran yang bervariasi dengan komposisi tumbuhan dan hewan yang kompleks. Berdasarkan jenis dan endemisitasnya, Indonesia merupakan salah satu pusat keanekaragaman hayati terbesar di dunia. Salah satunya adalah amfibi dan reptil yang mencakup sekitar $16 \%$ dari jumlah jenis yang terdapat di dunia dengan jumlah lebih dari 1100 jenis (Iskandar and Erdelen, 2006). Informasi terbaru hasil penelitian-penelitian yang telah dilaksanakan memperlihatkan bahwa jumlah tersebut masih jauh di bawah keadaan sebenarnya. Kemungkinan besar Indonesia bisa menjadi negara dengan jumlah amfibi dan reptil terbesar didunia, namun penelitian amfibi dan reptil di Indonesia jauh lebih lambat dibandingkan dengan kemajuan di negara tetangga.

Pada umumnya herpetofauna Indonesia tidak banyak dikenal, baik dari segi taksonomi, ciri-ciri biologi maupun ekologinya. Selain itu, daerah penyebaran suatu jenis juga sangat sedikit diketahui. Mengingat penebangan dan pengalihan fungsi hutan yang terus berlangsung maka perlu dilakukan usaha untuk melindungi komponen biologi (dalam hal ini amfibi dan reptil). Hampir semua status perlindungan baik secara nasional maupun dengan mengikuti kategori IUCN (International Union for Conservation of Nature) dan CITES (Convention on International Trade in Endangered Species) mengenai amfibi dan reptil belum banyak diketahui atau dipahami. Bahkan kebanyakan informasi mengenai herpetofauna Indonesia sulit diperoleh di dalam negeri (Iskandar and Ederlen, 2006).

Salah satu kelompok reptil yang sangat dikenal adalah ular yang diklasifikasikan kedalam ordo Squamata, subordo Serpentes (Ophidia). Saat ini terdapat 2500-2700 jenis ulardalam 414 genus dan 13 famili diseluruh dunia. Ular 
terdistribusi di seluruh permukaan bumi kecuali daerah Artik, Islandia, Selandia Baru, dan beberapa pulau kecil di lautan luas (Obst et al., 1988).

Penelitian tentang jenis ular yang terdapat di Indonesia telah dilakukan oleh beberapa peneliti antara lain mengenai ular kobra yang sangat berbeda dibandingkan Malaysia, Tailand, Jawa bahkan pulau-pulau kecil disekitarnya (Wuster dan Thorpe, 1987), mengenai biogeografi ular di Indonesia (How dan Kitchener, 1997), jenis dari genus Trimeresurus yang berwarna hijau dan coklat berasal dari Indonesia bagian barat telah dilakukan oleh ahli taksonomi asing selama sepuluh tahun terakhir (Malhotra \& Thorpe, 2000, 2004; David et al., 2001, 2002; Vogel et al., 2004; David dan Vogel, 2006 cit Sanders et al (2005)). David dan Vogel,1996 melaporkan bahwa di pulau Sumatera terdapat sekitar 128 jenis.

Sumatera merupakan pulau terbesar ketiga di Indonesia terletak di garis khatulistiwa, beriklim tropis dan memiliki Pegunungan Barisan dari utara ke selatan. Masih banyaknya daerah Sumatera yang ditutupi hutan dan vegetasi lainnya menyebabkan keanekaaragam jenis ular yang tinggi.Sebanyak 127 jenis, yang telah dilaporkan di Sumatera (David dan Vogel,1996). Namun demikian informasi mengenai penyebaran dan taksonomi ular di Sumatera masih sedikit demikian juga di Sumatera Barat. Salah satu jenis ular yang endemic di Sumatera Barat adalah Trimeresurus barati. Ular ini merupakan jenis ular berbisa yang aktif pada malam hari. Menurut David et al (2009) ular ini ditemukan dibeberapa daerah di Sumatera Barat diantaranya Sungai Kumbang Kerinci, Kabupaten Solok dan Padang. Namun belum ada informasi yang jelas mengenai keberadaannya di daerah-daerah lain di Sumatera Barat. Informasi tersebut tentunya diperlukan untuk mengetahui keberadaan herpetofauna khususnya $T$. barati yang endemik di Sumatera Barat sehingga dapat membantu upaya pelestarian di masa yang akan datang.

Berdasarkan uraian diatas peneliti tertarik untuk melihat keberadaan $T$. barati pada beberapa daerah yang terdapat di Sumatera Barat. 


\section{METODE PENELITIAN}

Penelitian ini dilaksanakan pada bulan Februari sampai Agustus 2015. Pengambilan sampel dilakukan pada beberapa daerah di Sumatera Barat diantaranya Paninjauan, Balingka, Matur (Kabupaten Agam), Batipuh, Sabu, Andaleh, Cagar Alam Lembah Anai, Tambangan (Kabupaten Tanah Datar) dan Alahan Panjang (Kabupaten Solok). Alat dan bahan yang digunakan antara lain headlamp/senter, GPS, termometer, karung, kantung plastik, karet gelang, sarung tangan, kamera digital, jarum injeksi, botol specimen, masker, botol sampel dan alat tulis. Bahan yang digunakan adalah etanol 70\%, aquadest, tissue gulung, formalin, sarung tangan.

Penelitian ini merupakan penelitian deskriptif dengan metoda survei, disertai penangkapan langsung di beberapa daerah di Sumatera Barat, pengumpulan informasi dari masyarakat dan identifikasi spesimen yang terdapat di Laboratorium Zoologi STKIP PGRI Sumatera Barat.

Penentuan lokasi transek dilakukan dengan pertimbangan habitat yang disukai oleh ular seperti semak, tepian sungai, akar pohon, dan percabangan pohon pada daerah perbukitan. Kemudian survei dilakukan sepanjang transek sepanjang satu kilometer disertai penangkapan langsung objek yang ditemukan. Pengambilan data suhu dan ketinggian.

Ular yang didapatkan dieksekusi dengan menginjeksi formalin $4 \%$ pada bagian atas kepala, kemudian diinjeksi dengan formalin $4 \%$ pada beberapa bagian tubuh dan ditutupi dengan tisu yang telah dibasahi formalin, kemudian dibiarkan selama satu malam. Setelah semalam spesimen dipindahkan kedalam botol sampel berisi alkohol 70\%. Identifikasi sampel dilakukan di laboratorium menggunakan jurnal dan buku-buku sebagai berikut ; David dan Vogel (1996); Vogel (2006); How dan Kitchener (1997); Iskandar dan Colijn, (2001); Phelps (1981); Malkmus et al (2002); Wuster dan Thorpe (1987); De Rooij (1917); Cox (1998); Inger dan Leviton (1991).

\section{HASIL DAN PEMBAHASAN}

Trimeresurus barati merupakan salah satu jenis ular yang aktif pada malam hari. Adapun taksonomi dari jenis ini adalah kingdom Animalia pada filum 
Chordata dengan subfilum Vertebrata, kelas Reptilia, Ordo: Squamata dengan Subordo: Serpentes dari kelompok famili Viperidae dengan subfamili Crotalinae yang tergolong genus Trimeresurus dengan species Trimeresurus barati (Regenass and Kramer, 1981).

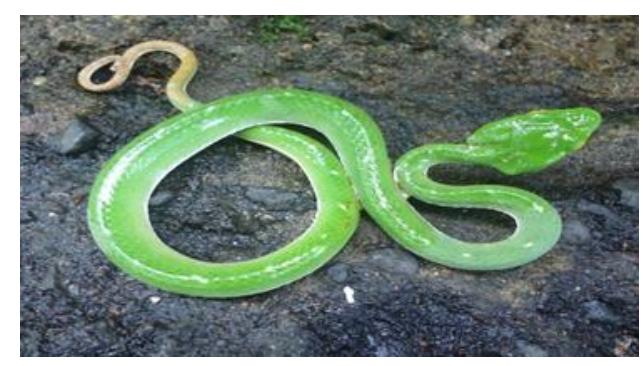

Gambar 1. Trimeresurus barati

Berdasarkan penelitian yang telah dilaksanakan mulai dari bulan Agustus 2014 sampai Juli 2015. Distribusi Trimeresurus barati yang terlihat selama penelitian terlihat pada Tabel 1 .

Tabel 1. Lokasi ditemukannya Trimeresurus barati pada beberapa daerah di Sumatera Barat

\begin{tabular}{|c|c|c|c|c|}
\hline Lokasi & $\begin{array}{l}\text { Jumlah } \\
\text { sampel }\end{array}$ & Ketinggian & Suhu & Habitat \\
\hline Paninjauan, Kabupaten Agam & 4 & $800-1000 \mathrm{~m} \mathrm{dpl}$ & $12-24^{\circ} \mathrm{C}$ & Hutan \\
\hline Balingka, Kabupaten Agam & 3 & 600-700m dpl & $15-27^{\circ} \mathrm{C}$ & Hutan \\
\hline Matur, Agam & 1 & 600-700m dpl & $15-28$ & Ladang \\
\hline Batipuh, Kabupaten Tanah Datar & 2 & 600-700m dpl & $15-30^{\circ} \mathrm{C}$ & Ladang \\
\hline Sabu, Kabupaten Tanah Datar & 1 & 700-800m dpl & $12-28^{\circ} \mathrm{C}$ & Ladang \\
\hline Andaleh, Kabupaten Tanah Datar & 1 & 700-800m dpl & $12-28^{\circ} \mathrm{C}$ & Ladang \\
\hline $\begin{array}{l}\text { Cagar Alam Lembah Anai, } \\
\text { Kabupaten Tanah Datar }\end{array}$ & 5 & 600-800m dpl & $18-28^{\circ} \mathrm{C}$ & Hutan \\
\hline Alahan Panjang, & 3 & 600-800m dpl & $12-24^{\circ} \mathrm{C}$ & Hutan \\
\hline \multicolumn{5}{|l|}{ Kabupaten Solok } \\
\hline Tambangan, Tanah Datar & 4 & 600-800m dpl & $12-24 \mathrm{C}$ & $\begin{array}{l}\text { Ladang- } \\
\text { Hutan }\end{array}$ \\
\hline Total Sampel & 24 & & & \\
\hline
\end{tabular}

Trimeresurus barati merupakan ular penghuni dataran tinggi yang terdapat dihampir seluruh daerah dijajaran Bukit Barisan di Sumatera Barat. Berdasarkan 
hasil yang didapat, ular berbisa dari jenis Trimeresurus barati memiliki habitat yang beragam mulai dari ladang masyarakat hingga hutan di perbukitan. Jenis ini sangat umum ditemui pada ketinggian 600-1000m dpl dengan suhu 12-30C.

Berdasarkan Tabel 1 didapati bahwa Trimeresurus barati banyak ditemukan pada daerah dengan ketinggian $600 \mathrm{~m}$ dpl hingga $1000 \mathrm{~m}$ dpl serta pada suhu $12^{\circ} \mathrm{C}$ hingga $28^{\circ} \mathrm{C}$ sedangkan pada daerah dengan ketinggian dibawah $800 \mathrm{~m}$ dpl sangat jarang ditemukan. Dari data tabel 1 diketahui T. barati banyak ditemukan di daerah Cagar Alam Lembah Anai. Hal ini disebabkan keadaan hutan masih terjaga sehingga keanekaragaman hayati yang menunjang kehidupan T. barati masih banyak tersedia. Selain faktor tersebut Cagar Alam Lembah Anai memiliki daerah yang luas meliputi jajaran daerah-daerah yang berbukit dengan suhu yang mendukung kelangsungan hidup jenis ini. Berdasarkan data pada tabel 1 keberadaan T. barati masih tersebar di beberapa daerah di Sumatera Barat, tentunya keadaan ini perlu dipertahankan sehingga keberadaan $T$. barati tetap lestari.

\section{KESIMPULAN DAN SARAN}

Trimeresurus barati terdistribusi hampir diseluruh dataran tinggi di Sumatera Barat. Berdasarkan penelitian yang telah dilakukan, disarankan pada peneliti selanjutnya untuk melakukan morfometrik dengan sampel yang lebih banyak.

\section{DAFTAR PUSTAKA}

x J. M. 1998. A Photographic Guide to Snakes and Other Reptiles of Peninsular Malaysia, Singapore and Thailand. New Holland Publishers (UK) Ltd. London.

Das, I. 2004. Lizards of Borneo. Natural History Publication (Borneo). Kota Kinabalu, Indonesia

David, P. et al. 2006. A Revision of The Trimeresurus Puniceus Complex Based on Morphological and Molecular Data. Zootaxa 1293: 1-78

And G. Vogel. 1996. Snake of Sumatra Seconde Edition. Edition Chimaira. Frankfurt, Germany

. 2000. On the Occurences of Trimeresurus Alholabris ( GPA 1842) on Sumatera Island, Indonesia. Senckenbergiana Biologica 80 (1/2): 225-232

De Rooij, N. 1917. The Reptiles of The Indo-Australian Archipelago II: Ophidia. E. J. Brill Ltd. Leiden 
Iskandar, D.T. and A.H. Prasetyo. 1996. The Amphibians and Reptiles of Pini and Tanah Masa Island, West Sumatra. Annual Report of FBRT Project No 2

Iskandar, D.T. and W.R. Erdelen. 2006. Conservation of Amphibians and Reptiles in Indonesia: Issues and Problems. Institut Teknologi Bandung. Bandung

Iskandar, D.T. and D.Y.Setyanto. 1996. The Amphibians and Reptiles of Anai Valley, West Sumatra. Annual Report of FBRT Project No 2

Iskandar, D.T. and E. colijn. 2001. A Check List of Southeast Asian and New Guinean Reptil Part I: Serpentes. Treubia 31(3): 1-195

Kuch et al. 2007. A New Species of Temple Pit Viper (Tropidolaemus Wagleri, 1830) from Sulawesi, Indonesia (Squamata: Viperidae: Crotalinae). Zootaxa 1446: 1-20

Malhotra, A and R.S. Thorpe. 2000. A Phylogeny of the Trimeresurus group of Pit Viper: New Evidence from a Mitochondrial Gene Tree. Molecular Phylogenetics and Evolution Vol. 16, No.2, August, pp.199-211

.2004. A Phylogeny of Four Mitochondrial Gene Regions Suggest A Revised Taxonomy for Asian Pit Viper (Trimeresurus and Ovophis). Molecular Phylogenetics and Evolution 32: 83-100

Malkmus et al. 2002. Amphibians \& Reptiles of Mount Kinabalu (North Borneo). A.R.G. Gantner Verlag K.G. Germany.

Sanders K.L. et.al. 2004. Ecological Diversification in a Group of Indomalayan Pitvipers ( Trimeresurus ). Convergence in Taxonomically Important Traits has Implications for Species Identification. Journal of Evolutionary Biology Vol. 17, Issue 4, 721-731

Sanders K.L. et.al. 2005. Combining Molecular Morphological and Ecological Data to Infer Species Boundaries in a Cryptic Tropical Pitviver. Biological Journal of the Linnean Society, 87, 343-364

Vogel, G. et al. 2004. A Review of Morphological Variation in Trimereserus Popeiorum with the Description of Two New Species. Zootaxa: 727: 1-63 . 2006. Venomous Snakes of Asia. Edition Chimaira. A.C.S. Glaser. Germany 